\title{
Twentieth-Century Museums of National History and Literature in Contemporary Russia
}

\author{
Adaptation of the Soviet Experience and \\ Crisis Management
}

The collapse of the Soviet Union in 1991 forced museums and other guardians of the nation's cultural heritage to reassess their priorities and develop new, nonideological missions in presenting their collections to the public.

Beginning in the late 1980s, economic and political changes caused Russia's museums, and other cultural institutions with them, to adopt a different working style, making adjustments that affected both managerial approaches and the content of exhibitions. The need for change was especially evident in museums of Soviet history and literature, whose profile positioned them as a link in the chain of ideological indoctrination and propaganda. They had to reconceptualize both their mission and their functional tasks.

Although the transformation of museums in the 1990s appears as a "postSoviet" phenomenon, the course that this process took should be analyzed in 
both the Russian and the international contexts. The transformations that museums are undergoing today are determined in part by the specificity of Russia's current societal organization as well as by the global cultural process.

This article represents a sociological study of museum management in a time of transition. It seeks to answer two questions: how the directors of museums of Soviet history and literature are interpreting the Soviet legacy, and what resources are available to them in converting their ideas into projects, exhibitions, and guided tours. The analysis tackles the new approaches to museum management and new constructs of museum activity, the ways in which museum staffs conceptualize their mission in society, and the interaction of the museums with other social and cultural sectors. This study also introduces the more general question of the nature of, and the forms wherein, the Soviet experience is being adapted in contemporary Russia.

My work is based on materials gathered within the framework of team research projects on the transformation of the cultural sphere in Russia over the past fifteen years. ${ }^{1}$ I examined museum exhibitions, newspaper and magazine publications, museum brochures and catalogs, websites, reports on the activity of foreign foundations that have funded Russian cultural ventures, and articles by experts in arts administration and cultural policy. I also have worked with materials on the daily life of museums with various profiles (history, literature, art, and area studies) in many parts of Russia. This article, however, limits itself to the close analysis of museums in the northwest (mainly in St. Petersburg) and the Volga region that are currently engaged in making the Soviet legacy generally accessible. ${ }^{2}$

The historical and literary museums of the Soviet period fall into two types: institutions founded in the Soviet period that have been revamped in recent years, ${ }^{3}$ and museums set up in the late 1980s, during perestroika. ${ }^{4}$ Museums of the relevant profile also differ widely: whereas in large cities such as St. Petersburg and Nizhnii Novgorod there are major specialized museums that throw light on the period of interest to us here, in smaller communities Soviet history may be confined to one room in an area studies (or school) museum. But my research objective at this stage was to map the similarities between various museums of Soviet history, rather than the differences between them. To accomplish the task at hand, many (enormously substantial) differences have been intentionally disregarded.

\section{Russia's Museums in the International Context: Old and New Management Methods}

Sociologists have explained the new turn in museum development that began in Europe and the United States after World War II by the advent of 
the consumer society and by the "cultural logic" of late capitalism. Despite substantial differences in museum management in various countries, several tendencies are common to them all. ${ }^{5}$

The number of museums, like the number of visitors, is growing by the year in all countries. As two Canadian sociologists have noted, they have come to replace churches and temples over the past two decades. In earlier times, not a single village, not a single neighborhood, was willing to live without a place of worship, which fulfilled the functions of societal integration. Today no inhabited locality cares to function without a museum of its own. ${ }^{6}$

From the eighteenth century on, the relations between museums and society have passed through three stages: that of governmentalization in the latter half of the eighteenth century; that of politicization and bureaucratization in the late nineteenth and early twentieth centuries; and, finally, that of democratization in the period since $1945 .^{7}$ Although museums were initially planned for the enlightenment of the public at large, they were long focused on the well-versed visitor, and their activity was primarily directed toward the collections themselves - their preservation, supplementation, and study.

Beginning in the 1960s, those "temples of the muses" took their place among several other cultural industries whose job was to create consumer identities and lifestyles. That being so, museums at that time faced the need to develop new cultural products and find the market for them and to evaluate their own activity in terms of economic effectiveness. Marketing (the study of consumer tastes, responsiveness to demand, and the creation of new requirements) became a significant element in museum management. While priority had previously gone to the artifacts themselves-collecting, classifying, and researching them-in the last thirty years, the prime emphasis has fallen on visitors and their requirements, by which is meant not only their cognitive and cultural needs but also their most prosaic and mundane wish list. Since the mass visitor's satisfaction depends on more than the quality of the exhibitions and guided tours, attention was now being paid to museum cafes and restaurants, gift shops, and all the miscellaneous infrastructure necessary to rest and relaxation. Museums were increasingly being transformed from repositories of art and artifacts into multiple-use cultural centers. ${ }^{8}$

In a certain sense, the changes of the 1990s in Russia's museums duplicated those global trends. During perestroika, for example, financial difficulties did not prevent the number of museums from increasing several times over, in both urban and rural areas. In Udmurtia, for instance, that number rose threefold: "When decentralization was underway in the 1990s, 
the district authorities began thinking of ways to shore up their image and preserve urban history, so they started creating museums. Museums began sprouting like mushrooms throughout the republic. There were fifteen or so altogether, and then there were forty" (Nadezhda Veniaminova Vechtomova, chief museums specialist with the Udmurt Republic's Ministry of Culture, 2004). ${ }^{9}$

The Russian situation differed in that here, unlike in other countries, museums had been "democratized" far earlier (in the 1920s and during the first Five-Year Plan [1928-1932-Trans.]) than elsewhere, and had never been defined by the idea of satisfying the requirements of the consumer of cultural products. The intention was, rather, the reverse, with the state mounting a campaign to "culturalize" the workers and encouraging them to visit cultural recreation venues, such as museums, theaters, and palace-park ensembles. ${ }^{10}$ Even in the late Soviet period, most of the visitors to museums of Soviet literature and history came in organized groups of tourists and schoolchildren, neither of which had much choice when it came to the museum exhibitions they were to see. The museum directors and staffs cared little about what actually interested their visitors. Speaking at a conference held to discuss new management skills in the museum realm, the director of the Central Naval Museum in St. Petersburg noted that over his many years of work during the Soviet period, however "snug" the conditions were, however "uninterrupted" the flow of budgetary funds, and however "adequate" the number and size of organized visits, "the museum's team had adopted a stable stereotype that held the museum's work to be exclusively for itself, to the benefit of its staff. Work with visitors, the study of their requirements, formally the be-all and end-all, was in fact for many long years more honored in the breach." 11

From the early 1990s on, attracting visitors and satisfying their demands became priorities, and from approximately 1993 or 1994, museum directors were having to learn the new management methods that their establishments needed if they were to develop in this different world. The new managerial skills may be divided into two types: first, the aptitudes needed to interact with the municipal administration or the Ministry of Culture (depending on whether the museum in question relies on funding from the federal, republican, or municipal budget), and second, the ability to draw on foreign experience in the sphere of museum management.

\section{Interaction with Administrative Entities}

Russia is unlike many other countries in that it has retained the Soviet system's hierarchical system of cultural management. As "subordinate 
institutions" [podvedomstvennye uchrezhdeniia], museums still have to rely on senior bureaucrats. In some of Russia's municipalities and regions, museum directors and the heads of cultural departments (committees, directorates) are at loggerheads, while the former have virtually no clout with the authorities. And for this reason, much in these hierarchical relations is determined by the specific situation: in some cases, the museum director interviewees expressed themselves grateful to the local administration, whereas others used their interviews as an opportunity to protest. It cannot, however, be said that cultural institutions are unambiguously the injured parties or that they are always forced to adapt to the requirements of superior entities. Given that the situation in the cultural sphere is so new to the authorities, dating back only to the 1990s, the rules of engagement have been, and are still being, worked out jointly by both sides.

Representatives of administrative entities generally noted in their interviews that, given the shortage of budgetary funds (an objective fact of life), the possibility of receiving assistance from the local authorities does indeed depend on how active a particular cultural institution is and that persistent and well-founded appeals are what it takes to get government decision makers to come up with resources or to assist the cultural institutions in their search for sponsors.

With rare exceptions, budgetary funds still form the bulk of the revenue stream for Russia's museums. But the earmarked resources are as a rule insufficient, making it essential to "scrounge" or "shake loose" (to quote some interviewees) additional budgetary funding by bringing convincing arguments and personal connections to bear. To raise the money for a given project, the museum heads exploit various "hooks" [informatsionnye povody] such as anniversaries; events of municipal, republican, or nationwide importance; and political elections. The interaction between museum heads and the local administration is described by both sides as a rather complex process that demands thorough preparation and subtle diplomacy:

"Shaking loose" money from a finance committee or a cultural committee is very complicated. Every time we write a cost estimate for the coming year, it comes back to us at the beginning of the year in a distorted, mangled form that has been reduced some five or six times over. ... Two years ago, I finally put together a program for equipment financing and wheedled $\$ 33,000$ out of the finance committee to install that equipment. ... After I won the tender, even buttoned-down men from the finance committee came and tapped me on the shoulder, 
wanting to know "How did you manage to wedge us apart over something like that??? That hardly ever happens!" (a chief museum curator, St. Petersburg).

During their interviews, small-town museum heads in Russia's outlying areas, who have fewer opportunities than their colleagues in big-city museums, often named interaction with the authorities as their greatest problem: "The skills to interact with the regime are greatly needed. It's more than the brain can handle. This is a professional team, but we are all budgetary organizations. We can attract the resources for specific undertakings from various foundations. That's all good. But interacting with the power structure ... How do you make yourself a priority to government agencies?" (a deputy museum director, Kirov).

The professional museum associations that began to appear during perestroika are helpful in resolving many problems. The Union of Russian Museums was set up quite recently, in 2001, preceded by the Union of Creative Museum Employees of St. Petersburg and Leningrad Oblast (1989), the Society of Museum Employees of the Volga Area, and the Open Museum and Museum of the Future associations. Not all museums participate in the activities of professional groups, but those that are members see them as a huge help in what they do:

"Peter" has a Union of Museum Employees. We all socialize together and see one another quite often. If any general exhibitions come up, we join in. If anyone needs to ask for help-methodological, creative, human, professional—or for things to put in an exhibition, it's all done without money, without honorariums, for free. I don't even know which museums we don't interact with. ... I consider what has been done here to be a great achievement of the past decade. A director is a lonely, a very lonely, thing to be. But that was then, because now there's the union. There you chose the people closest to you and keep your distance from those who are less your type. And so on. You arm yourself with experience. You arm yourself with advice. And I can come for advice, ask my questions. Of course, you mainly get it yourself, that experience, but sometimes you need someone to offer pointers, to provide his own notes. That bears on relations with the authorities. Monetary, budgetary, legal matters. We have a legal counsel in the union who works for our union. That, now, is very important. To be legally protected and to understand the meaning of what is happening, especially since it's a big mess out there with the laws and what you can and cannot do. That, now, is very important. That is professional support (a museum director, St. Petersburg). 


\section{New Managerial Skills and Foreign Experience}

In their search for new managerial approaches, museum staffs largely take their bearings from international experience. And they have been helped in this by professional development programs [programmy povysheniia kvalifikatsii] that feature international experts.

Beginning in 1993 and 1994, several foreign traditions of art management came simultaneously to Russia. I note, however, that the concept of "foreign experience" in museum management is not entirely on point, since the differences between countries in this area can be significant. There are at least two identifiably distinct models, the American and the European. Many American museums live on sponsors' donations and endowments, whereas most European museums are predominantly budgetary entities. ${ }^{12}$ But European countries also exhibit enormous distinctions in this area. In France, for example, the cultural sphere has for many years been generously funded from the national budget, and the commercialization of museums has become an active subject of discussion only in the past few years. In Great Britain, unlike France, museums had their funding slashed during the Thatcher years.

From the early 1990s on, the heads of Russia's museums were given the opportunity to share experience with museum managers from various countries, by attending seminars and practical courses [treningi] in Russia and by going for training abroad. ${ }^{13}$ Their ability to be involved in programs such as these was mostly made possible by foreign foundations and, from the late 1990s on, by facilitators in Russia. ${ }^{14}$ Since then, at least four hundred seminars and courses have been held for arts administrators in Russia, of which about one-third was designed specifically for museum decision makers. Additionally, museum managers have been given the opportunity to attend educational programs on cultural policy.

Discussions at those events have included the structure of the museum sector, the mobilization of internal reserves, and ways of attracting additional sources of funding. The seminar programs also covered studying museum audiences; taking care of museum visitors; coordinating with travel agencies, sponsors, and the press; setting up museum stores and cafes; publishing; engaging in long-range planning, public relations, advertising, strategic management, time management, and partnering; issuing recommendations on using museum facilities for functions unconnected with the museum's usual activities; putting together developmental constructs; writing business plans; and correlating a museum's construct with the tasks of municipal and regional development. Initially, the new managerial skills in the greatest demand were marketing 
and fundraising, the fundamentals of project-based thinking, grant writing, and work with sponsors. Other front-burner topics were the establishment of peer-to-peer connections and business contacts with other museums, and the organization of partnership networks and joint projects. ${ }^{15}$ Museum heads noted that there was also cooperation between directors in the Soviet period, but it was of a fundamentally different kind: no one then was talking about "project-based thinking" [proektnoe myshlenie] or organizing joint activities "in project tempo" [ $v$ ritme proektov], and there was less impetus to team up.

Museum management has, however, been unevenly engaged in these educational programs. Some museum heads have attended numerous programs, both in Russia and abroad, since the mid-1990s, while others began taking advantage of them only two or three years ago. A portion of attendees found the programs very useful, whereas others assessed them as unnecessary and preferred not to waste time on them. Certain heads have successfully blended various managerial methods, to the point at which the museums they supervise have become to a significant extent self-sufficient, although that is more the exception than the rule. At the opposite pole are those who have made no changes at all in their exhibitions, their guided tours, or their working methods since Soviet times and have no inkling of the contemporary methods of art management that are essential to a museum director in a capitalist-type society.

It is the general consensus among experts that cultural institutions are still coming up against many unresolved issues. ${ }^{16}$ At the present time, the main problem for Russia's museums is a shortage of middle-range staffthe complexities attendant on finding well-trained young high flyers who have been groomed to work both proficiently and innovatively. Interacting with museum personnel, motivating staff, and maintaining a team spirit are at the present time a complex challenge for many directors. Young cultural managers who have been through professional development programs in Russia and abroad are looking for high-paying jobs in the large cities. The big-city museums do, to be sure, objectively offer more opportunities to develop and seek funding. But even in the most remote corners of Russia there are museum managers who work on a global plane, actively cooperating with regional, national, and international professional associations.

It is important to understand today that, the need to surmount the legacy of the Soviet period notwithstanding, Russian museums are on the whole facing the same problems that confront museums in other countries. Their development, too, links into economic, political, and societal processes. A groundbreaking structurizing idea right now is that of culture as a tool of 
territorial development, which entails a corresponding need to mold cultural policy on a municipal and regional level. In many parts of Russia, though, this way of doing things is less in the implementation stage than stuck on the drawing board, although both arts administrators and regional leaders still have every intention of pursuing it. ${ }^{17}$

By implication, the idea of municipal development through culture places a heavy load on museums, in terms not only of keeping themselves alive and providing "cultural leisure activities" to the local population and tourists but also of creating "brands" and memorable projects and promotional events that will further communication with other cultural institutions and bring attention to the region. One of the museum's functions is to create an image of its territory or region, and the most successful managerial strategies, as a rule, facilitate the fulfilment of that function. ${ }^{18}$ From the standpoint of developing communication between territories in the cultural sphere, a large role goes to projects that anticipate the involvement of several museums. Several such initiatives have been carried out in various regions over recent years, one example being the Siberian Highway [Sibirskii trakt] project, a program being undertaken by museum staffs in the Udmurt Republic:

For three years now, our museum has been part of the large and complex Siberian Highway regional project. A large stretch of Russia's major transportation artery, the Siberian Highway, runs through Udmurtia. But our territory is unique in that near the village of Debesy, the two branches-the Moscow and the Petersburg-come together, forming a single road that goes all the way from Udmurtia to Siberia. This prompted the idea for a project to create an exhibition that would travel all the way along the Siberian Highway. We are going to take it throughout Udmurtia, to all our eight Siberian Highway districts [raiony]. It will run for a month in every district on the Udmurtian stretch of the Siberian Highway. Right now a written proposal for using the Siberian Highway project from the viewpoint of its historicocultural and natural heritage is in the completion stage. And this year, the project enters its next phase. We have already announced a competition called "The Design of the Road," which solicits ideas for the styling of that space.

The road could be made a tourist route: within the project framework we have to present three highway-adjacent tourist routes to the Volga Federal District [federal'nyi okrug]. We also have a dream of reviving the tradition of market days in the villages along the Siberian Highway. We are trying to enlist entrepreneurial help in setting up the first traveling fair in at least two villages. But by and large our present task is 
to create a Siberian Highway association that would include those museums and the district administrations. The possibilities are endless for us to develop on the strength of our cultural resources (Marina Borisovna Rupasova, deputy director for core activities at the Kuzebai Gerd National Museum of the Udmurt Republic, 2004).

In Russia (and worldwide) the aesthetization of the past is ever more popular, and the interest in folk festivals, folk crafts, and regional history is growing. The search for one's roots is becoming a concern not just of the individual but of entire societal groups. The processes ongoing in Russia today are comparable with those in Europe in the 1970s, when disappointment with the idea of progress and the positive effects of modernization set in. Those changes have been accompanied by a rise in the attention paid to the history of "silent" societal groups and areas far distant from Moscow and St. Petersburg. Modern times, as sociologists have observed, are "obsessed with memory." 19 The increase in the number of museums and memorials attests, in Pierre Nora's opinion, to the onset of an "age of commemoration," whose hallmark is that the memory of the past is brought to the fore and suddenly comes into high demand, actually vying with the official history offered by textbooks and encyclopedias. ${ }^{20}$ Regional museums are creating a unique mosaic of memories. In present-day France, the castles of the aristocracy are being transformed into museums that have to jockey for position with museums of rustic lifeways and rural crafts. ${ }^{21}$ And for all the seeming originality and occasional "Kunstkammerism" of the post-Soviet space, it exhibits many similar processes. A rejection of everything ethnic, archaic, dated, and local in favor of the new, the contemporary, and the countrywide characterized the USSR as it did the other industrial powers. But at present, in this new phase, a unique kind of "return to the wellsprings" is there for all to see, as the cultural legacy in Russia (and all over the world) is transformed into a resource for the deployment of economic and political strategies.

\section{The Crisis of the 1990s in the Long History of Ideological Crises}

Analyzing the development of Russia's cultural institutions over the past fifteen to twenty years, experts in arts administration and sociologists have noted that, on the whole, museums adapt to a transitional situation better and more easily than other cultural institutions. One explanation for the success that the once ideological Soviet museums have had in the transitional period is the experience of surviving under extreme conditions that they acquired in Soviet times. A retrospective examination of the history of museums in this country shows that their upheavals and 
difficulties under the Soviet regime were at least as daunting as those that museums were encountering only a decade ago. Current museum employees still remember legends of the preceding period's crises, which have been passed down from generation to generation.

Throughout its existence, the Museum of the October Revolution, predecessor to the current State Museum of the Political History of Russia, repeatedly met with harsh criticism due to changes in the political climate:

The museum created its permanent exhibition in the late 1920s, but it was hardly finished before major events - events that were tough for the country to bear-began occurring. Kirov was killed in 1934, in December. And already in January 1935, immediately after all those events, the Leningrad Oblast Committee of the All-Union Communist Party (Bolshevik) adopted a special resolution on the Museum of the Revolution, which stated that the exhibition was contaminated with hostile literature and its construct was erroneous in that it had overestimated the role of the populists and so forth, failing to criticize them from the appropriate standpoint, and had underestimated the roles of Lenin and Stalin in the October Revolution. An instruction was given to shut everything down fast and redo everything just as fast. The employees, naturally, did all this. The exhibition was partially redone in a mere six months. And very many interesting things that prior to this time had been in the exhibition were consigned to the vaults. It came closer and closer to doing what agitprop was designed to do. All the achievements of all the five-year plans had to be shown, up to and including a roster of pig farms in Leningrad Oblast. All the same, the museum held on until 1937-1938. Then the repressions affected it as well. Many people who worked at the museum were repressed. When The History of the All-Union Communist Party (Bolshevik): Short Course [Kratkii kurs istorii $\operatorname{VKP}(b)]$ was issued, naturally an instruction ensued to restructure the whole exhibition to match the Short Course. And so began a period that was very tough to bear, because the exhibition and everything the museum did had to be constantly restructured in accordance with whatever the current directive happened to be. We began doing all that as best we could. Some things we got done, some things we didn't, but then the Great Patriotic War broke out. And the museum found itself in the sorriest state possible: it had no exhibition at all. But none of this means that the museum employees were busy with nothing but nonsense like that, ideological nonsense. ... They did quite a few useful things, especially when it came to bringing various items in our city into the museum. The postwar period was probably the toughest to bear in the museum's history. The collections were, of course, being purged all the time, being purged of enemies of the people, with 
photographs destroyed, negatives trashed, and so on. Still, it wasn't a wholesale crackdown. What was not on display but down in the vaults stayed safe. But then, in the late 1940s and early 1950 s... there was a slew of purges, especially after the far-famed Leningrad Affair. Verifying commissions went through the vaults doing their job. We still have documents on file from that time. The result was the demise of thousands of valuable exhibits-White Guard posters, leaflets, and other documents, for example. And not only White Guard materials but also leaflets and posters that mentioned the names of Trotsky, Kamenev, and other "enemies of the people." They were destroyed in any of several ways. Our most senior employee, a department head, a woman who came on staff in 1952 and was here through all of this, told me that it was something like the fascist book burnings, but on a rather smaller scale, of course.... There were fires lit all over the Peter and Paul Fortress grounds, and there they burned some very characteristic and eloquent White Guard posters- "Commissars on Red Square" and "Lenin and Zinov'ev Are Ravaging Russia," in which Russia was portrayed as a woman. The fact is that this perished, was destroyed. (Aleksei Mikhailovich Kulegin, deputy director, Museum of the Political History of Russia, 2000).

The predecessor of today's Museum of the Defense and Blockade of Leningrad, which was founded in 1946, existed only until 1953, when it was closed and many of its exhibits were destroyed:

The clouds gathered over it as early as 1949, in connection with the Leningrad Affair. All else aside, when Malenkov came here to have it out with the local Leningrad Party and economic leadership, he had it out with the museum into the bargain. What was the motive? "How come you're glorifying yourselves and your superiors (meaning [Petr Sergeevich] Popkov and suchlike persons of interest relative to the Leningrad Affair)? Why the underestimation of Stalin's role, the role of the entire country, in the defense of Leningrad? All you talk about is the special role, the special situation of Leningrad" (Valerii Mikhailovich David, deputy director of the Museum of the Defense and Blockade of Leningrad, 2000).

According to the sociological construct developed with respect to individuals or discrete groups descended from those who have weathered adversity, they find it easier to adapt to complex situations, since they have generations'-worth of accumulated and transmitted experience in overcoming difficulties. That idea can probably be applied to museums, too, in the sense that the memory of overcoming ideological crises eased their transition to the new political climate of perestroika. A sense that museums 
of Soviet history and literature were about to lose their ideological legitimacy emerged as early as the latter half of the 1980s. Even before financial problems surfaced, the heads of those "museums of ideology" realized that they would need to completely recast their goals and tasks in order to remain relevant to a society undergoing political transformation. The Museum of the October Revolution, for example, was closed for four years to be "reappraised" and in the early 1990s rose again in the new guise of the State Museum of the Political History of Russia:

The preceding permanent exhibition, which was kept open until 1987, was entirely devoted to the Party's leading role in the revolution. That exhibition had been planned during the period of stagnation, rested wholly on the historical scholarship of the time, and showed, to all intents and purposes, only one party. And for that reason we were forced to close it in $1987 \ldots$. That year was distinctive for its extremism, for the way in which everything was being demolished, wrecked, and for the assumption that everything that had existed during the Soviet period was bad (and especially the Great October Socialist Revolution, as it was called back then). And so, in order not to damage the exhibits, to hurt the museum's image, we left untouched only things that would still be set in stone many years later. We left the great hall of the armed uprising; we left the rooms that commemorate Lenin and the Central Committee of the Bolshevik Party .... All the rest—which was, generally speaking, shown with bias-we closed and began wondering what to do next. And it was not until 1991 that we got on track with an academic council in which we explored a new construct for the museum's development. In 1991, we adopted a developmental construct that would work quite a way into the future: until historical doctrine stabilized, until new original sources appeared, until the archives were opened, we decided to show Russia at developmental watersheds and put up problem-centered exhibits. The "History of Russian Parliamentarism" exhibit, for example. We raised funds, studied the materials, and made a history of our state dumas as they existed under the tsar and [as they are-S.Ch.] today. Then we showed the history of the economic development and genesis of entrepreneurship in Russia. Because in 1991, the public at large and even many scholars really knew nothing about that. And new entrepreneurs came to us, just to see what stocks looked like. After that, we made an interesting exhibit called "The History of Political Parties" (Marta Petrovna Potiforova, at the time of the interview director of the Museum of the Political History of Russia, 2000).

Today, in 2005, that museum, which has federal status (meaning that it is recognized as a museum not of local but of national scope), has more than 
ten exhibitions of various kinds, all relating in one way or another to the political history of Russia from the 1860s to the present day.

The "Thank You, Comrade Stalin" exhibition (Man and Power in the USSR in the 1930s-Early 1950s) displays the history of the Stalinist period as the history of the subordination of private interests and private lives to the tasks of the state (the authorities). Its main points of interest are photographs and documents, both official and personal (the latter being letters and diaries), with the official documents on arrests and exiles standing in stark contrast to the diaries and letters of the arrested and exiled. The personal effects of political leaders lie side by side with articles that belonged to political prisoners. Here, too, is the reconstruction of the office of a key administrator and of an average Soviet construction worker's typical bunkhouse. The sounds of 1930s dance music alternate with songs of the Gulag, and one can also hear original recordings of speeches by the country's leaders. The explanatory labels in each display case, which are given in both Russian and English, interpret the Stalinist period as a time when people were steamrolled by an all-powerful regime. That vision of the Stalinist period is closest of all to the interpretations of the totalitarian school of Soviet studies, which were fully shared by the Russian reading public during perestroika and showed Stalinism primarily as the tragedy of a people victimized by those in power. But attentive visitors will also discover here some interesting documents, especially personal ones, that will allow them to develop their own reading and learn certain facts that until now had not been available anywhere.

But even the most recent period of change is now becoming history, becoming memory. If the exhibition on the time of Stalinism is compared with the "Awaiting Change" exhibit, which is dedicated to the twentieth anniversary of perestroika, the latter may be seen not as a clear chronology of display cases but as an array of symbolic objects whose job is to remind the visitor of the 1980s' turbulent end. The magazines Ogonek and Burda moden are here, along with footage of congresses and Gorbachev's meetings with foreign leaders. Commemorative items - the video camera that Gorbachev used at Foros and the notes he took-are also on display. Perestroika is symbolically portrayed in the form of an unfinished barn haphazardly plastered with newspaper clippings and posters promising the advent of a "new thinking," "socialism with a human face," glasnost, and cost accounting [khozraschet]. Unlike the exhibit on Stalin's time, which gravitates largely toward a historical interpretation of events, the perestroika exhibit gives more of a sense of one emotionally charged pinprick after another. Even the preliminary remarks from the exhibit's curators in the catalog attest to this: "Obviously, the museum's 
interpretation of the period of 1985-1987 does not plumb the depth and exhaust the variety of what we call the Gorbachev perestroika. It may, however, perfectly well serve as grounds for reflection on how the country and your life has changed in twenty years."

Unlike the Soviet period, when neither the museums themselves nor the city's residents could openly cast doubt on decisions dispensed from on high, perestroika was characterized by an overt struggle between diverse interests and political views. But at the most complex ideological turning point, which coincided with the economic crisis, the museums of Soviet history and Soviet heroes received moral support, first, from a town or city's residents, especially those who opposed perestroika; second, from foreign tourists visiting Russia for the first time, who were enormously interested in seeing everything "Soviet" there was to see; and finally, from colleagues abroad with professional ties to a given museum's thematic orientation.

As the general attitude toward the writer whose name the city of Nizhnii Novgorod had recently borne was perceptibly souring, the locals, local businesspeople among them, were supporting the Gor'kii Museum with gifts and other one-of-a-kind tokens of their regard:

It was Gor'kii's birthday, and this was just as the surge of negativity was cresting. One company learned that Gor'kii's relatives were arriving, and there would be literary readings. When I came into the museum lobby, I found several boxes of Gor'kii brand vodka. Somebody had just come and put them there. As a gift. That's some sponsor. Now that has stopped, but earlier we-and especially the Kashirin House [Gor'kii's childhood home-Trans.] - had constant support. On Gor'kii's birthday, champagne was brought in. At that time there was a surge of negativism, and in those gestures, people were showing how much they disagreed with what they had heard about Gor'kii. They wanted to support us. Although that surge was officially endorsed, there was another one underneath. This was very curious to us; it kept us going as well (Tamara Aleksandrova Ryzhova, director of the A.M. Gor'kii State Museum, 2004).

In the waning days of perestroika, when the ideological heroes of yore found themselves under attack, the Chapaev Museum in Cheboksary went through hard times as well. There was even talk of converting it into a museum of military glory named for Chapaev, but that never materialized. That was when the museum and local business people began doing each other a unique set of favors. Attached to the museum is a building known as the Chapaev Hut, where the hero was born and lived until leaving to fight in the Civil War. By special arrangement, the hut can be booked for business 
meetings during which the actual or prospective partners drink tea around a samovar after going on a brief guided tour. A superstition holds that commercial agreements come together wonderfully well in the Chapaev Hut, and that drinking tea there bodes success for any business venture. ${ }^{22}$

But solidarity on the part of locals and tourists notwithstanding, the number of visitors to museums of Soviet history and literature fell appreciably in the 1990s. This was due, first, to the disappearance of organized tourist groups from other urban areas and the socialist countries (as mentioned earlier, visits to such museums were part of the compulsory program) and, second, to a decline in Russian visitors' interest in events, people, and facts that were definitive of the official construct of the USSR. In the past few years, the number of visitors to those museums has again been rising on the strength of their work with school and college students and their cooperation with travel agencies. Museum heads note that a few years ago they stumbled into the latest "crisis of ideas," which was attributable to the fact that many events in Soviet history had yet to be "objectively" evaluated by historians from the vantage point of the present day. But meanwhile, a new generation of visitors made an appearance in the late 1990s - a generation that did not even remember the Soviet years and needed a different contextualization of the exhibitions than would be appropriate for their older contemporaries. Currently, the most complicated period to interpret is that of World War II. While collectivization, industrialization, and the Stalin repressions were the topics of numerous discussions during perestroika, wartime events were not reevaluated at that time from the current perspectives. As the deputy director of the Museum of the Defense and Blockade of Leningrad noted in his interview, people were coming to the museum "to view articles from the Blockade in a certain aestheticized environment," and therefore the museum staff's task was "to place those articles in the context of what a given person knows about the War and the Blockade." Although they had, as the interviews demonstrated, a fairly precise idea of their terms of reference, the museum employees still felt that they were playing second fiddle to historians and sensed that they were missing the overarching constructs they needed to present the exhibits properly:

To this day, the whole truth about the war, and not even that but also all the benchmarks of what we do know have not been altogether distributed as they should be. Because if they are distributed as they should bemeaning in keeping with common sense-then, from the war's very outset, there is no way, other than as a devastating failure and primarily as a managerial failure on the part of Soviet power, to explain the entire 
series of egregious blunders that in fact triggered the misfortunes that assailed the country and our city. There are public items and private items here. Speaking specifically of the topic that is of concern to us here, that topic will always remain until society has been able to think it through and understand what kind of a regime it was (V.M. David, deputy director of the Museum of the Defense and Blockade of Leningrad, 2000).

We are presently only a few decades away from events that recent generations of visitors are already perceiving as fairly ancient history. On the other hand, that history does not yet exist, because it quite simply has not been written. Many archives are still to be opened; certain facts and events have yet to be studied and processed. But that is why the notion of some museum heads that they are secondary to historians may be called into question by reference to the highly substantive and in some ways irreplaceable role of museums in the present societal context. At this time, less (read: hardly anything) of what they do is intended to supplement the official history and more (most of it, in fact) is designed to add to the memory that is transmitted through informal interaction with still living eyewitnesses. And for that very reason, as the following section shows, museum exhibitions are now centering their attention on the memory of person, thing, and place.

\section{New Museum Constructs: The Assimilation of the Soviet Legacy}

The post-Soviet period is characterized by the shaping of the new identities that are coming to supersede their Soviet predecessors. While previously the exhibitions and guided tours were predetermined to a significant extent by interpretations handed down from on high, in the 1990s museum constructs were being created based on requirements supplied by audience. Employees began to analyze who came to their museums and why and conducted visitor surveys to inquire into what was missing from the exhibitions and what their clientele would like to see. ${ }^{23}$

\section{The Memory of Place}

When museums dedicated to the history and literature of the Soviet period were seeking their place in contemporary society, one of several possible working strategies they came up with was to produce a new identity for their town or city or for one of more of its individual topoi. This "discovery" came simultaneously to many of Russia's museums, which became "custodians of the memory of the little homeland" [malaia rodina, the local 
area-Trans.] that was familiar to visitors from their own recollections or from stories they had heard. Museums see their function as that of rendering the memory of the distant past less trite, of stripping from it the stereotypical readings that had been prescriptively assigned to it both in the Soviet period and, partially, in the period that followed.

St. Petersburg's Anna Akhmatova Museum at the Fountain House [Fontannyi dom], which was set up in 1989, has been transformed into a cultural center that hosts, in addition to the main permanent exhibition, various artistic and literary events, such as poetry readings and displays of contemporary art. The museum's very name partly reflects its construct, since "Anna Akhmatova" and "the Fountain House" are, to all intents and purposes, characters of equal ranking here, while behind them lurks the uncredited cast member that is St. Petersburg: "For our ideology, the palace and the garden are 90 percent of the meaning. Akhmatova lived here for thirty-five years, from 1917 through 1952. This is a Petersburg museum, a museum of Petersburg culture; it is the only Petersburg museum in which a twentieth-century poet's apartment has grown from the palatial culture, from the ancient, aristocratic, traditional, familial culture, contiguous with it and true heir to it. This is unique in St. Petersburg. There is no other like it."

The location of the museum in the Fountain House, which is both where "Poem Without a Hero" [Poema bez geroia] was composed and a character in that poem, has encouraged the exhibitions' curators to place special emphasis on the continuity of Russia's cultural history, on the sequentiality between the Silver Age and Soviet (albeit unofficial) art and literature. It may be said that the Fountain House puts a very different complexion on the entire history of twentieth-century Russia:

The message to people is that the history [presented-S.Ch.] through Akhmatova's world, through her eyes, is continuous and that within it a splendid Soviet period cannot be differentiated from a bad Soviet period. It is continuous. And when the revolution and all that followed began, Akhmatova was one of the few who was not appalled, on the one hand, and who nurtured no illusions, on the other. She knew that there had been Batu Khan, there had been the Time of Troubles, there had been civil wars, and that this people would now joyfully exterminate each other. But the spiritual light, the light of culture, must be carried forward, as the first Christians carried it into the catacombs. And it must survive. Survive until this too should pass. And pass it did. And God gave her a long life. And she emerged with that light again. When this comes across to visitors through the agency of words or whatever else, this is what opens up to them, and they find it wildly interesting. Because we did not know how to 
carry history on like that, she went ahead and split herself up for us. She was both "good" and "bad"; she began 1917 in appalling form, but only the few who took a philosophical view of Russia could understand the continuity of the process (Nina Ivanovna Popova, director of the Anna Akhmatova Apartment Museum, 2001).

The continuity of the Leningrad-Petersburg nexus (which many cultural figures and many Petersburgers question) is one of today's widely debated hot topics that are important not only to every resident but also to the city's overall developmental strategy. And so the museum met society's requirement, while simultaneously mapping the unique fate of a unique person.

The embedding of Leningrad's history into the palatial context of St. Petersburg, the faceoff between revolution and tradition, the creation of new and sometimes eclectic readings is an altogether typical strategy for museums that specialize in the history of Leningrad's culture, which can be largely attributed to their being located in mansions and palaces. For example, the branch of the Museum of the History of St. Petersburg (formerly Leningrad), at no. 44 on the English Embankment, which offers exhibitions on everyday life during the New Economic Policy period, the period of "socialist reconstruction," and the 1940s, is housed in the former Rumiantsev Palace. After a Sunday stroll along the embankment, the visitor enters the luxurious palace, ascends the grand staircase, and goes to peruse the daily life of the petty bourgeois, the bonnets and ribbons, the menus from public eateries and taverns, the Soviet posters and phonograph records, the recreation of a communal kitchen, a propaganda room, a bomb shelter, artillery shells, documents from the Blockade, and military tunics. But there is also an exhibition dedicated to the palace itself and its outcomes in various historical periods.

The Museum of the Political History of Russia, formerly the Museum of the October Revolution, occupies a mansion that until 1917 had belonged to the ballerina Matilda Kshesinskaya and from March to July 1917 served as the Bolshevik headquarters. (Lenin regularly delivered speeches from its balcony.) At present, the visitor will find in the museum, along with the permanent and temporary displays that are dedicated to various aspects of Russia's political and economic history, one exhibition that tells of the Bolsheviks' time in the mansion and another that presents Kshesinskaya's life story. Since the history of the mansion itself is every bit as contradictory as the political history of Russia, the interplay of interpretations, which encompass the history of the building, the history of the city, and the history of Russia, is both germane and successfully done, especially since, by 
breathing new life into the traditions of this place, it enables the expansion of the museum's functions, which currently include the hosting of musical evenings and political salons.

The interweaving of palatial culture and revolutionary events is also used to good effect in the Smol'nyi Museum:

The museum that exists today was created in 1991. It was not the successor of the Vladimir Il'ich Lenin Museum with just a change of name. Today it is called the Smol'nyi State Historical and Memorial Museum in St. Petersburg. In the intervening years an exhibition was set up to show Smol'nyi's prerevolutionary history, which is basically the history of the Smol'nyi Institute for Nobly Born Young Ladies.... So we began with the Smol'nyi Institute, which was, in point of fact, Quarenghi's reason for constructing this building. We created the exhibition. Now we have significant holdings dedicated to the Smol'nyi Institute. We also managed to track down the last remaining alumnae of Smol'nyi. Meaning that this is one side of what we are doing todayrecreating Smol'nyi's prerevolutionary history. The exhibition is up and running; the holdings dedicated to that theme are in place. That was the first thing we did.

Then there was "Smol'nyi: the Days of Blockade" - another exhibition we created. The thing is that during the Blockade, Smol'nyi was the building where it all began and all ended, and the fate of the city largely depended on what happened at Smol'nyi. And since both the city's civil leaders and its military leadership were here, for that reason this was also the building's finest hour. We called the exhibition "Smol'nyi: the Days of Blockade" because we have both the Museum of the Blockade and the Piskarev Cemetery here, so naturally we in no way claimed to be putting on an extensive presentation of the events of the Blockade. Instead, we set ourselves the task of showing Smol'nyi during the Blockade. And some unique documents stamped "Top Secret." Smol'nyi has had a very interesting life, a very interesting biography. Buildings, like people, have a fate of their own. And it is one of a kind, even today (Valentina Sergeevna Tiutcheva, director of the Smol'nyi Historical and Memorial Museum, 2000).

While a feature of the "accommodation" of the Soviet legacy to modern life, that reconceptualization ultimately also impinges on the more distant past. New interpretations arise from the comparison of diverse epochs. Seemingly incompatible elements come together, and this also engenders new cultural facts, occurrences, and brands. In the quest for a new way of looking at the events of the Soviet period, exhibition organizers and visitors alike turn to both the time before the revolution and the here and now. 
A museum of the Soviet period puts a fine ideological point on issues pertaining to history's discontinuity versus its continuity, to the reproducibility and irreproducibility of human experience, and to the singular status of this particular territory (that last question being raised in one form or another by all museums).

\section{The Memory of a Generation: From Political History to the History of the Everyday}

After the flurry of attention given to political history in the late 1980s, the educated public's interest shifted to the history of the everyday. The exhibitions' heroes came down from the pedestals, all but blending in with their contemporaries, the "just plain folks." They were somewhat demythologized and brought closer to the observer, to the past that every visitor knows, if not from personal experience then from stories told by his or her parents. The directors of museums expressly dedicated to the heroes of the Revolution emphasized [during their interviews-Trans.] that they have deliberately chosen not to expand on political themes or allude to the history of ideas. Not only have the museums been deideologized but also the heroes of the revolution have been in some way humanized.

The museums of Leningrad/St. Petersburg featuring the life and work of V.I. Lenin have been visibly transformed. Some Lenin museums (for example, the one in Leningrad's Marble Palace) were even shut down altogether during perestroika. But others (Smol'nyi, the Elizarov Apartment Museum, the Allilueva Apartment Museum, and the Museum of the Revolutionary and Democratic Movement) are still open for business. The memorial apartments occupied by Lenin at one point or another in his active life are now presenting themselves as museums of the everyday that showcase the general household arrangements of the radical intelligentsia of the late nineteenth and early twentieth centuries through the specific circumstances of its leading man. The figure of Lenin, his contradictory policies, and the development of his ideas fade into the background, giving way not to what made him original but to what made him typical. The head of the Elizarov Apartment Museum spoke of this in her interview:

It is thanks to the Lenin Museum, which never, ever closed, that this unique apartment-the only one that presents so fully the lifeways of the turn-of-the-century intelligentsia to which the Elizarovs belonged-has been preserved in our city. We are not propagandizing anything, not touting any ideology. We are showing you what was. We are not interpreting. We are illuminating the activity of our apartment and generally the activity of everyone who lived here. That would be all the 
Ul'ianovs, and all the Elizarovs, and Vladimir Il'ich. Of course, we touch on the events of 1917, that being April-July 1917, when Lenin lived here. At some later time we plan to throw a modicum of light on the history of Petrograd District. This is exactly where the city came into being. Then the neighborhood was forgotten. But, you see, our house marked the very outskirts of St. Petersburg, even in 1917. So we are also intending to pursue the topic of Petrograd District (Nelli Petrovna Privalenko, head of the Elizarov Apartment Museum, 2001).

Other Lenin-associated museums formulate their mission in approximately the same way. For example, in 1993, the Lenin Museum on Cossack Lane (formerly Il'ich Lane) became the Museum of the Revolutionary and Democratic Movement, where visitors are presented with scenes from the daily lives of the radically inclined "mild-mannered tenants" [tikhie uglovye zhil'tsy; literally, "the quiet corner tenants," but the corner could actually be-as it was in this case-a separate room-Trans.]:

After the collapse of the previous ideology and the cult of Lenin in the early 1990s, the museum naturally had no choice but to change. It found the certain something it needed in the history of the daily life of Petersburgers on the cusp of two centuries. Lenin's room, which remained from the previous museum, slotted ideally into the museum's new construct as well as its new exhibition. Because then it could all be viewed from a completely different angle, seen as the typical subleased room, intact and untouched. Wilhelm Ferdinand Karl Bode, an émigré from Switzerland and the apartment's primary lessee, worked at the Synod's printing house. He and his family leased the entire apartment, subletting one of the rooms for extra income. One of his roomers was a legal assistant named Vladimir Ul'ianov, who lived here for more than a year-from 12 February 1894 to 25 April 1895-filling his time not only with clandestine activities but also with the responsibilities of his job, traveling from here on official business to the district court on Liteinyi Avenue, walking to the office of the justice of the peace on Meshchanskaia Street, and to attorney conferences. His sublessors were very pleased with their quiet, calm lodger who did not smoke or drink or play a musical instrument. ${ }^{24}$

The Smol'nyi Museum also changed its presentation of Lenin's study, to "humanize" the man who led a revolution:

We have naturally preserved Lenin's office, except that we have packed it with things to which people could relate more closely. For example, we hung up a cloth cap. We hung up Nadezhda Konstantinovna's hat. Vladimir Il'ich bought his cap in 1917, on his way to Russia; it's French. 
We hung up an umbrella. Meaning that individual features have been introduced to humanize the office, which unquestionably arouses people's interest. We placed furniture that should have been there, that really was there, but then we took it away. All the Lenin museums used to be identical. But now we have set it up as it really was. So we present the Soviet period from the standpoint of what happened here; that's how we show it. And that's why I told you from the start that there's no ideology here (V.S. Tiutcheva, director of the Smol'nyi Historical and Memorial Museum, 2000).

Other apartment museums also see their task in portraying "the everyday life of the intelligentsia." Here is another excerpt from the interview with the director of the Akhmatova Museum:

From my point of view, the museum's subtext, the idea behind it, is that of a museum dedicated to the history, fate, and life of the Leningrad intelligentsia of the 1920s, 1930s, 1950s, 1960s. ... Strictly speaking, what we have here is a museum of Petersburg's twentieth-century literary history, culture, and poetry. Aside from the Zoshchenko Museum, this is the only apartment that offers so much as a notion of how people, how the artistic intelligentsia of the twentieth century lived. ... The task is to look beyond what happened to Akhmatova and from there to chart what happened to Leningrad's intelligentsia (N.I. Popova, director of the Anna Akhmatova Apartment Museum, 2001).

In formulating what their institutions are all about, museum employees very often speak of a desire to show "everyday life" and "the fate of a generation." Given that approach, the distinction between the two "protagonists" and even the polar opposition of the initial master plans for the Lenin Museum and the Akhmatova Museum are deemphasized in favor of showcasing the typical traits of "milieu" and "epoch." The mythologized historical personage complete with a biography that may be the stuff of legend but is for all that still one person's life story is replaced by the homogenized and equally mythologized image of an age. Although there are as yet virtually no apartment museums displaying the everyday life of workers and other population strata, such museums could well appear in the foreseeable future, if the track record of European countries and the gradual migration of interest toward the lives of "just plain folks" are anything to go by.

\section{People and Extraordinary Circumstances}

Some museums of Soviet history and literature accentuate the study of life in a transitional time, by way of a person's adaptation to extreme 
circumstances. Others, by contrast, emphasize that it is possible for individuals to create the context of their own lives, demonstrating how people can influence their social environment. The Museum of the Defense of Leningrad sees its mission in using surviving articles and documents to show a person living in the time of the Blockade. The experience of such a person is unique, and, now that a certain historical distance stands between present-day society and the 1940s, the Blockade presents to us as a tragic human experiment. The museum's exhibition studies the boundaries of human capacity by displaying the medical, psychological, and sociological aspects of the Blockade experience.

There were various attitudes during the war. Some would lie down and die, others would scrape through. It's always that way. Completely incomprehensible as that is.... Given what they had to eat, everyone should have died. Even so, they didn't. They held out through that terrible winter. The most terrible, the hardest to bear. They held out with massive losses. To this day we are still counting the fatalities. We will never have the exact number. Yet the weather began to warm, and they started planting vegetable gardens. Under fire, no less. They had to, since the Germans put the city under siege in late August-early September. The fight was very grave, very serious.... That experience is massively significant. Not only for our country, though - for everyone. What people can do!... On the other hand, there is a negative side. It is hard to show that in a museum, but there are ways of bringing it into the discussion. Well, people in that condition, of course, lose their human persona. That's a fact. There's nothing you can do about it. It's a tragedy. So, first of all, people should never be reduced to that condition. Second, and this is big, even though there was cannibalism and such in this huge city, it was not on a mass scale. Even though we know from literature and history what people in an enclosed space will come to. There have been instances when people forced to overwinter have killed each other. But that did not happen on a mass scale during the Blockade. Why? What factors were operating here? (V.M. David, deputy director of the Museum of the Defense and Blockade of Leningrad, 2000).

Museums dedicated to the political prison camps raise similar questions. Behind the exhibitions of camp life, articles, photographs, documents, and maps, one glimpses the fate of people in extraordinary circumstances. But as studies show, the museums of the Gulag (now numbering more than three hundred throughout the country) present today as "an aggregate of geographically diffused, thematically and methodologically disjointed initiatives launched by committed individuals and professional teams." 25 
Yet behind the image of "people in extraordinary circumstances," one discerns no ownership of responsibility. Studies show that "victims there are, but no one is to blame" is the most bearable interpretation of the past in areas where the descendants of victims and their executioners, of those who were deported and those who deported them, live side by side. Furthermore, the reluctance to talk about responsibility is accompanied by the idealization of the period preceding the repressions and deportations. Memories of the good old days become a collective myth, a refuge from the not-so-old days of awkwardness and ambiguity. ${ }^{26}$

\section{People and the Great Idea}

Personal memorial museums offer an idiosyncratically "anthropological" approach. They study the fate of a person during a time of transition through his or her biography and environment. For example, the common ground linking the exhibitions in the Maksim Gor'kii museums of Nizhnii Novgorod and Kazan is the writer's spiritual quest, the revolutionary and literary context engendered by his activity, and the impact of the new milieu that formed under the influence of his ideas and endeavors on the city's intellectual life. According to T.A. Ryzhova, director of the A.M. Gor'kii State Museum in Nizhnii Novgorod, Gor'kii's principal interest to visitors lies in the fact that he represents a Russian who lived up to his potential and "made something of himself." Someone studying Gor'kii's personality today is in a sense looking at himself in the mirror and seeing the enormous opportunities and hazards of both a strong character and a time of transition. ${ }^{27}$

Andrei Sakharov's Memorial Apartment Museum in Nizhnii Novgorod also touches on the problem of human potential, of the power and authority of great ideas. That museum occupies two apartments. The one where Sakharov and Bonner lived preserves the setting of the late 1970s and early 1980s. The other houses an exhibition of Sakharov's life story, his activity in science and human rights; and almost all of its materials are also available in English, which is truly unique for a memorial museum in the Russian provinces. The reason for this is that $30-40$ percent of visitors are foreigners.

The heads of the Sakharov Museum have downplayed the ideological underpinning of Sakharov's activity, endeavoring instead to show what happened to a person who was in many respects unconventional while not playing up his dissidence: "We tried to make a factual exhibition dominated neither by a political orientation nor by any other slant" (Liubov' Vladimirovna Potapova, director of the Sakharov Apartment Museum, 2004). 
But the state-owned efficiency apartment [kvartira gostinichnogo tipa] occupied by Sakharov and Bonner is in itself an eloquent monument to the Era of Stagnation and predetermines how the exhibition is perceived. The visitor finds himself in an uncomfortable space, a sight so disheartening as to leave one at a loss to know how anybody could have spent years in a place like this. That emotional sensation is very powerful, and undoubtedly manifests differently in those who remember the 1970s and 1980s and in younger visitors and foreigners. The space is therefore more "ideologized" than the exhibition itself.

Given that there is today no stable construct of Soviet history, place (with its memory of events) together with the person and his memory have become the sole "historical truth" that can be presented to the museum visitor in a time of indeterminacy and mutually contradictory interpretations. That approach is based on the opinion that it is easier for a mistrustful observer trying to make sense of the country's transitional periods to move from the particular to the general. The biography of a place and an individual person interwoven with events in the history of the country and the city has therefore become the most frequent and actively sought-after way of presenting materials in Russia's museums.

\section{Museum Shrines, Soviet History, and Contemporary Society}

As the French philosopher Jean-Louis Déotte has noted, society needs museums so that it can forget. ${ }^{28}$ By examining museums of Soviet history from that point of view, we can at least try to formulate what our society is already beginning to forget, what it remembers, and what it passes over in silence, reluctant to say the words.

In contemporary Russia, the museums that specialize in Soviet history and literature find a ready audience in both local residents and tourists. The museums with research associates on staff base their developmental construct on their own and others' research, taking their bearings from the requirements and remit of the prospective audience. "Who comes to the museum and why?" is what they really want to know today. Museums use their ideas of visitor demands and of their own role in their municipality's cultural space as their starting point in formulating their societal functions, developmental strategies, and specific tasks for the foreseeable future.

Our research has shown that the pendulum of interpretations of the Soviet period has swung to the other extreme from its pre-perestroika position. Prior to perestroika, as museum employees recall, they were obliged to show the causal necessity [zakonomernost'] of the revolution, of the development of Soviet society, and of the general course of sociocultural processes. 
Today, however, the Soviet period is presented as an inexplicable accident, as an improbably chaotic time during which exceptional individuals and ordinary people showed their caliber in different ways. As a contemporary strategy, the "Abandonment of Ideology" [Ukhod ot ideologii] has induced museums to portray the personal, the typical, the ordinary, the local, the national, or whatever else might serve to illustrate the specific nature of Soviet civilization.

If we were to attempt to frame a "composite" picture of the exhibitions of Russia's museums of Soviet history and literature, it would look something like this. The typical pince-nez-sporting "mild-mannered tenants," back from emigration, rented the mansions of nobly born young ladies, who then took their turn in emigration. The salon spaces did not lie vacant, though, but continued functioning as they always had. But there were fewer heroes of the revolution with every passing year. The photographs were retouched, the names forgotten. And at the same time, regular people were doing all they could to battle hunger and cold. They were experimented on, but they did not surrender. They sewed fashionable outfits and danced the foxtrot. In the hungriest years, they laid out vegetable gardens in the cities and waxed nostalgic about the past. Some of those living in unbearable conditions kept diaries, composed plays and songs, drew, and made soft toys for children. They wrote letters "to those in power" [vo vlast'], insisting on their allegiance. But those in power did not reciprocate. Human potential was, to all intents and purposes, boundless. It became clear that even an average person could preserve his or her dignity in extreme circumstances. The larger than life were also able to actualize their talents, despite it all. But ideology was obviously fiercely inimical to people, the simple and the great alike.

This mythologized picture of the Soviet past exhibits an inextricable fusion of melodramatic kitsch and authentic testimonials to the tragic experience of generations, a mix of consequential documents and amusing curiosities made to satisfy the idle curiosity of present-day observers. More often than not, this fixation on "ideology avoidance" [bezydeinost'] leads to inconsistency and eclecticism (in which only a very detached researcher could see elements of postmodernism) and potentially encompasses two wholly contradictory types of historical awareness-a nostalgia for a "great age" now long gone and the total rejection of any vestiges of "Sovietism." Contemporary societies are called "postmodernist" because they seek to transcend the rationalism of the modernist worldview, which led to the implementation of two horrific utopian projects (fascism and communism). Inasmuch as the experience of living under totalitarianism proved exceedingly painful and impinged on the most intimate spheres of human 
existence-emotions, private life, family memory-it has become evident that this trauma cannot be eliminated through rationalist explanations and rationalizations, however logical and convincing they may be. Societies obsessed by their past are therefore trying today to identify not rational but, rather, emotional ways to free themselves from the burden of horrific memories, making the aesthetic organization of the display space as important to contemporary museums as the exhibits themselves. Museums are thus becoming an arena for the work of the emotions, which makes it possible to own and understand the past with all its traumas.

In some countries, alongside memorials erected at the regional sites of the events in question, a different type of museum is appearing in the capitals to generalize and evaluate what the regional museums show specifically through concrete materials. Two examples of this are the recently opened Holocaust Memorial [Denkmal für die ermordeten Juden Europas] in Berlin and the House of Terror [Terror Háza] in Budapest. Here the architecture, building design, and other artistic devices help problematize the attitude toward the past and ultimately achieve catharsis. The appearance of these "museum shrines" [muzei-khramy] in the capitals of states whose local residents have been implicated in the extermination of their Jewish populations speaks to the fact that Europe's societies are ready and willing to emotionally process and own their responsibility for that tragedy. ${ }^{29}$

Since the early 1990s, not one "museum shrine" has been built in Russia with the express purpose of liberating people from the pressure exerted by the past through the acknowledgment of collective responsibility. There is to this day no museum of the Gulag, and Russia's principal "shrine" of secular memory is still the Lenin Mausoleum. This suggests that, despite the work done by regional museums of Soviet history and the emergence of contemporary interpretations of the Soviet legacy, the experience of what life was like in the Stalinist period remains a secret, an unhealed social trauma, many aspects of which have been held under wraps in official readings of the past.

\section{Notes}

1. "St. Petersburg: Post-Soviet Identifications" [Postsovetskie identifikatsii Peterburga] (Renvall Institute, Finnish Academy of Science and Letters, 1999-2003, project supervisor Professor Elena Hellberg-Hirn) and "Evaluation of the Effectiveness of International Professional Development Programs for Russian Arts Managers" [Otsenka effektivnosti mezhdunarodnykh programm povyshenii kvalifikatsii rossiiskikh menedzherov v sfere kul'tury] (CEC International Partners and the Center for Independent Sociological Research, 2004, project supervisors Katerina 
Gerasimova and Susan Katz). The interviews cited were conducted by the author. This article does not utilize any of the material collected on Moscow museums.

2. Areas were selected that provided examples to illustrate this article's basic tenets; only museums that the author was able to visit in person were included. The Northwest and the Volga Region are special in that the opportunities to study new management methods were greater there than elsewhere in Russia. On the cultural and societal milieu in the Volga Region, see V.L. Glazychev, Glubinnaia Rossiia, 2000-2002 (Moscow: Novoe izdatel'stvo, 2003).

3. The Museum of the Political History of Russia (formerly the Museum of the October Revolution) in St. Petersburg, the Smol'nyi Historical and Memorial Museum in St. Petersburg, the St. Petersburg Museum of the Revolutionary and Democratic Movement, the S.M. Kirov House Museum in St. Petersburg, the A.M. Gor'kii museums in Nizhnii Novgorod and Kazan, the Chapaev Museum in Cheboksary, and the Elizarov Apartment Museum in St. Petersburg.

4. The Anna Akhmatova Museum at the Fountain House in St. Petersburg and the A.D. Sakharov Memorial Apartment Museum in Nizhnii Novgorod.

5. Giep Hagoort, Art Management: Entrepreneurial Style (Delft: Eburon Uitgeverij, 2000).

6. Laurier Turgeon and Élise Dubuc, "Musées d'ethnologie: nouveaux défis, nouveaux terrains," Ethnologies, vol. 24, no. 2.

7. François-René Martin, "Politique et culture: les musées et le patrimoine" (PhD diss., Université Robert Schuman de Strasbourg (Strasbourg-III), Institut d'études politiques, 1995).

8. Edward P. Alexander, Museums in Motion: An Introduction to the History and Function of Museums (Nashville: American Association for State and Local History, 1979).

9. See also http://www.museums.udmweb.ru [URL nonfunctional January 2016-Trans.].

10. K. Gerasimova and S. Chuikina, "Ot kapitalisticheskogo Peterburga k sotsialisticheskomu Leningradu: izmenenie sotsial'no-prostranstvennoi struktury goroda v 30-e gody," in Normy i tsennosti povsednevnoi zhizni: stanovlenie sotsialisticheskogo obraza zhizni v Rossii v 1920-e-1930-e gody, ed. T. Vikhvainen [Timo Vihvainen] (St. Petersburg, 2000), pp. 27-74.

11. E. Korchagin, "Magazin pri muzee," in Materialy rossiisko-britanskogo seminara "Muzei Sankt-Peterburga v usloviiakh rynochnoi ekonomiki, ed. A.D. Margolis (St. Petersburg: Kontrfors, 1997).

12. An endowment [endoument] is the donation by a private party, a bank, or a company of a sizable sum to a museum that the museum is not permitted to spend but instead invests (in consultation with outside financial experts) and receives regular income from those investments.

13. There are several long-term European programs that help send museum policy makers abroad: the Euro-Arctic Diploma in Cultural Management (Barentsadjacent countries), the European Diploma in Cultural Project Management, an educational program of the Regional Museum Council of Yorkshire and Humberside (Great Britain), and Courants du Monde (France). The United States also has programs of its own: study visits under the auspices of the US Department of State (the Open World Leadership Center), IREX training programs, and specialized programs for museum directors supported by several foundations. 
14. Museum projects in Russia have been actively sponsored by foreign foundations, an especially large role in this going to the Culture Program of the Open Society Institute (Soros Foundation) [now the Open Society FoundationsTrans.]. With that foundation's support, many museums have been computerized, and numerous professional development programs have been established. See Muzei v epokhu peremen: Institut "Otkrytoe obshchestvo" (Fond Sorosa)-Rossiia $v$ podderzhku rossiiskikh muzeev, 1966-2000) (Moscow: Ob' edienennoe gumanitarnoe izdatel'stvo, 2001). Programs for Russian arts managers within Russia have also been funded by the US State Department, the European Union, the European Commission, the Eurasia Foundation, the Ford Foundation, the Trust for Mutual Understanding, the J. Paul Getty Trust, the Kettering Family Foundation, the McCormick Foundation, the Samuel H. Kress Foundation, the Starr Foundation, the Fund for Arts and Culture in Central and Eastern Europe, and the foreign ministries of various countries. Among Russian organizations offering short-term seminars for art managers, the Muzei budushchego [Museum of the Future] association specializes in setting up training sessions for museum employees (http:// www.future.museum.ru).

15. See, in particular, E. Soboleva, "Formirovanie martketingovoi orientatsii muzeev Sankt-Peterburga," in VI World Congress for Central and East European Studies: Divergencies, Convergencies, Uncertainties: Abstracts (Tampere: International Council for Central and East European Studies, 2000), p. $403 \mathrm{ff}$.

16. M. Gnedovskii, "Mezhdunarodnye obrazovatel'nye programmy dlia rossiiskikh menedzherov kul'tury-itogi desiatiletiia," http://www.cpolicy.ru/ news.plx?id=242 [http://www.culturalmanagement.ru/infocenter/?cid=9\&aid= 598-Trans.].

17. The most interesting implementation of the idea of regional development through culture is the Cultural Capital of the Volga Region [Kul'turnaia stolitsa Povol'zhia] program, which is directed by S.V. Krivenko in the Volga Federal District, http://www.culturecapital.ru [http://fc-amkar.org/eng/europe/-Trans.].

18. Kul'turnyi turizm: konvergentsiia kul'tury $i$ turizma na poroge XXI veka: Uchebnoe posobie, ed. Ia. Braun, V. Andersen, and V. Gordin (St. Petersburg: Izdatel'stvo Sankt-Peterburgskogo gosudarstvennogo universiteta ekonomiki i finansov, 2001).

19. Daniel J. Sherman, The Construction of Memory in Interwar France (Chicago: University of Chicago Press, 1999)[p. 10-Trans.].

20. P. Nora et al., Frantsiia-Pamiat', trans. from the French (St. Petersburg: Izdatel'stvo Sankt-Peterburgskogo gosudarstvennogo universiteta, 1999) [a translation of seminal texts from Pierre Nora's Lieux de mémoire-Trans.].

21. Éric Mension-Riggau, La vie des chateaux (Paris: Éditions Perrin, 1999).

22. Interview with Valentina Ivanovna Brovchenkova, director of the Chapaev Museum (Cheboksary, 2004).

23. On this, see Margolis, Muzei v period peremen.

24. S. Glezerov, "Tipichnyi uglovoi zhilets Vladimir Ul'ianov," Nevskoe vremia, 1 February 2001.

25. Virtual'nyi muzei GULAGa. Obzor resursov (St. Petersburg: Nauchoissledovatel' skii tsentr "Memorial"), DVD; Konrad Adenauer Stiftung [Foundation]; the Perm-36 Memorial Museum; the National Museum of the Komi Republic; Prodiuserskii tsentr "Artikam," 2004. 
26. E. Zhessa-Anshtet [Elisabeth Gessat-Anstett], "Pamiat': vechnaia ili kurinaia? Memorial'naia logika v postsovetskoi Rossii," Ab imperio, 2004, no. 1, pp. 519-38.

27. T.A. Ryzhova, "Muzei A.M. Gor'kogo: problemy i poiski (k 75-letiiu so dnia osnovaniia)," Nizhegorodskii muzei, 2003, no. 1, pp. 21-24.

28. Jean-Louis Déotte, Oubliez! Les ruines, l'Europe, le musée (Paris: l'Harmattan, 1994).

29. See also [Laurent Gervereau, ed.,] Musées d'histoire et histoire dans les musées. Actes du séminaire du 17 juin 1992 (Paris: Association internationale des musées d'histoire / Direction des musées de France / Ministère de l'éducation nationale et de la culture, 1992). 